\title{
Indeks Formula Eritrosit Untuk Uji Skrining Talasemia Beta Minor
}

\author{
Doni Setiawan ${ }^{1}$, Hendri Setiawan $^{2}$, dan Ary Nurmalasari ${ }^{3}$ \\ ${ }^{1,3}$ Program Studi Teknologi Laboratorium Medik, Sekolah Tinggi Ilmu Kesehatan Muhammadiyah Ciamis, Jawa Barat, \\ Indonesia \\ ${ }^{2}$ Program Studi Keperawtan, Sekolah Tinggi Ilmu Kesehatan Muhammadiyah Ciamis, Jawa Barat, Indoensia
}

\begin{tabular}{l} 
Article Info \\
Article history: \\
Received Sep $17^{\text {th }} 2021$ \\
Revised Sep $26^{\text {th }} 2021$ \\
Accepted Sep $26^{\text {th }} 2021$ \\
\hline
\end{tabular}

\section{Keyword:}

Thalassaemia,

Screening,

Red cell indice,

RDW

\begin{abstract}
Erythrocyte indices have been used as the first indicator in screening for beta-thalassemia minor. However, iron deficiency in hemoglobinopathies can reduce the sensitivity of screening, and the spectrum of mutations of different hemoglobinopathies between populations will result in discontinuation of the results of different erythrocyte indices. The research objective in this study was to determine the description of the erythrocyte indices used to screen for beta-thalassemia trait in Ciamis. The research method used in this study was a quantitative descriptive, using a cross-sectional study, data collection had been done during March-May 2021. The subjects of this study were 104 parents of a beta-thalassemia trait who have children with a beta-thalassemia major in Ciamis. The examination parameters used were complete blood count, with processing twenty-six erythrocyte formula index values. Ninety-two respondents were included in the inclusion criteria. The results of the erythrocyte indices in beta-thalassemia trait are England and Fraser, RBC, Mentzer, Srivastava, Shine and Lal, Ricerca, Green and King, Das Gupta, Jayabose, Telmissani-MCHD, Telmissani-MDH, Huber-Herklotz, Kerman I, Kerman II, Sirdah, Ehsani, Keikhaei, Nishad, Wongprachum, Sehgal, Pornprasert, Sirachainan, Bordbar, Matos and Carvalho and CRUISE has cut-off value in that range according to previous studies. Only the Bessman erythrocyte indices has a value of 17 , exceeding the cut-off. Twenty-five erythrocyte indices with cut-off value according to previous studies can be used for beta-thalassemia screening in Ciamis, except for the Bessman erythrocyte indices.
\end{abstract}

\footnotetext{
ABSTRAK

Indek formula eritrosit, telah digunakan sebagai indikator pertama dalam skrining talasemia beta minor. Namun adanya defisiensi zat besi pada hemoglobinopati dapat menurunkan sensitivitas skrining dan spektrum mutasi hemoglobinopati berbeda antar populasi yang akan menghasilkan cut-off hasil indeks formula eritrosit yang berbeda. Tujuan dari penelitian ini yaitu mengetahui gambaran indeks formula eritrosit yang dapat digunakan untuk skrining talasemia beta minor di Kabupaten Ciamis. Metode penelitian ini menggunakan metode deskriptif kuantitatif, dengan teknik cross-sectional, yang telah dilakukan sejak bulan Maret-Mei 2021. Subjek penelitian adalah 104 orang talasemia beta minor yaitu orang tua yang memiliki anak talasemia mayor di Kabupaten Ciamis. Parameter pemeriksaan yang digunakan adalah hematologi rutin, dengan pengolahan 26 nilai indeks formula eritrosit. Dari seluruh responden yang bersedia dan masuk dalam kriteria inklusi adalah sebanyak 92 orang. Hasil indeks formula eritrosit pada talasemia beta minor di Kabupaten Ciamis yaitu Mentzer, England and Fraser, RBC, , Srivastava, Ricerca, Green and King, Shine and Lal, Das Gupta, Matos and Carvalho, Jayabose, Telmissani-MDH, Telmissani-MCHD, Kerman I, Kerman II, Sirdah, Huber-Herklotz, Ehsani, Keikhaei, Nishad, Bordbar, Sirachainan, Wongprachum, Sehgal, Pornprasert, dan
} 
CRUISE memiliki nilai dalam range cut-off sesuai penelitian sebelumnya, kecuali indeks formula eritrosit Bessman yang memiliki nilai 17. Keduapuluh lima indeks eritrosit dengan nilai cut-off sesuai penelitian sebelumnya dapat digunakan untuk skrining beta talasemia di Kabupaten Ciamis, kecuali indeks formula eritrosit Bessman .

Kata Kunci : Talasemia, Skrining, Indeks Eritrosit, RDW

\section{Pendahuluan}

Setidaknya 5,2\% populasi dunia (lebih dari 360 juta) membawa varian hemoglobin, dan diantaranya lebih dari 100 juta merupakan pembawa talasemia beta (talasemia beta minor) dengan frekuensi global 1,5\% (Hossain et al., 2017). Penduduk Indonesia tercatat dan menunjukkan prevalensi talasemia beta minor yang tinggi, yaitu 3-10\%. (Husna et al., 2017). Di Kecamatan Ciamis sendiri berdasarkan penelitian tahun 2020 ditemukan 5\% pelajar SMK merupakan talasemia beta minor (Setiawan et al., 2020).

Talasemia beta minor secara klinis asimtomatik atau hanya anemia ringan, tipe talassemia ini merupakan keadaan heterozigot dimana hanya satu alel dari kerusakan gen $\beta$ pada kromosom 11 dan alel lainnya normal. Talasemia beta minor diwariskan dari salah satu orang tua yang mengalami mutasi atau kelainan pada kromosom 11. Tetapi bila seorang talasemia beta minor menikah dengan sesama talasemia beta minor maka keturunanya berpeluang mengalami talasemia beta mayor (Husna et al., 2017).

Kelahiran bayi talasemia beta mayor merupakan kemalangan yang mempengaruhi baik pasien maupun orang tua. Oleh karena itu perlu strategi untuk uji skrining yang kuat sehingga dapat mengidentifikasi pasangan yang berisiko memiliki pembawa gen Talasemia beta. Metode yang digunakan haruslah sederhana dan sangat sensitif. Program uji skrining massal, terutama di negara berkembang di mana sumber daya terbatas, haruslah hemat biaya. Karena murahnya biaya pemeriksaan indek formula eritrosit, parameter ini telah digunakan sebagai indikator pertama kemungkinan talasemia beta minor. Nilai MCV dan MCH tidak hanya terbukti menjadi prediktor yang sangat tidak akurat dari genotip orang tua, tetapi juga memiliki multiple cut-off point (antara 70-80 untuk MCV dan 20-30 untuk MCH). Hal ini mengharuskan pengembangan indeks formula eritrosit yang lebih akurat. Sejak awal 1970-an, indeks formula eritrosit merupakan parameter pemeriksaan darah rutin yang telah disarankan sebagai alat yang mudah dan murah untuk menentukan apakah seseorang merupakan talasemia beta minor atau bukan. Namun parameter ini memiliki variasi akurasi yang berbeda (Bordbar et al., 2015). Indeks formula eritrosit yang telah digunakan untuk skrining talasemia beta minor yaitu Mentzer, England and Fraser (E\&F), RBC, Srivastava, Shine and Lal (S\&L), Ricerca, Green and King (G\&K), Bessman (RDW), Das Gupta, Jayabose (RDWI), Matos and Carvalho (MC), Telmissani-MCHD, TelmissaniMDH, Huber-Herklotz, Pornprasert, Sirachainan, Bordbar, Kerman I, Kerman II, Sirdah Ehsani, Keikhaei, Nishad, Wongprachum, Sehgal, dan CRUISE (Jahangiri et al., 2019).

Beberapa penelitian telah dilakukan untuk menentukan sensitivitas dan spesifisitas indeks formula eritrosit untuk uji skrining talasemia beta minor. Kesimpulan dari penelitian tersebut menunjukkan bahwa indeks formula eritrosit merupakan metode yang mudah dan dapat diandalkan untuk mendeteksi talasemia beta minor. Dimana persentase indeks formula eritrosit yang dapat mendiagnosis talasemia beta minor yang tertinggi yaitu indeks Mentzer (91\%), diikuti oleh indeks Ehsani et al. (84,8\%). Namun adanya defisiensi zat besi pada hemoglobinopati dapat menurunkan sensitivitas skrining dan spektrum mutasi hemoglobinopati berbeda antar populasi yang akan menghasilkan cut-off hasil indeks formula eritrosit yang berbeda (Surjawan et al., 2017). Tujuan Penelitian ini adalah untuk mengetahui gambaran indeks formula eritrosit yang dapat digunakan untuk skrining talasemia beta minor di Kabupaten Ciamis

\section{Metode Penelitian}

Penelitian ini menggunakan desain penelitian deskriptif kuantitatif mengaplikasikan teknik crosssectional. Populasi dalam penelitian ini adalah talasemia beta minor yaitu orang tua yang memiliki anak talasemia mayor di Kabupaten Ciamis, dengan besar sampel 94 subjek. Pengambilan sampel dilakukan sesuai dengan kriteria. Kriteria inklusi orangtua penderita talasemia mayor, memiliki nilai MCV $<80 \mathrm{fL}$ dan bersedia mengikuti penelitian, serta mengembalikan informed consent yang telah ditandatangani. Kriteria eksklusi yaitu penderita talasemia dan spesimen darah lisis.

Penelitian dilakukan pada bulan Maret sampai dengan Mei 2021. Sebanyak 104 subjek bersedia mengikuti penelitian, dan 12 subjek diantaranya tereksklusi, sehingga data yang digunakan dalam penelitian ini hanya 92 subjek. 
Pengambilan spesimen menggunakan darah yang mengandung antikoagukan EDTA (Ethylenediaminetetraacetic acid) sebanyak $3 \mathrm{~mL}$. Pemeriksaan dilakukan di Laboratorium Klinik STIKes Muhammadiyah Ciamis, Ciamis, Jawa Barat. Pemeriksaan hematologi terdiri dari Hb, jumlah eritrosit, Hematokrit, RDW, MCV, MCH, dan MCHC. menggunakan hematology analyzer (Sysmex XP-100, Sysmex Corporation, Japan).

Data dianalisis dengan menggunakan program pengolahan data excel. Penelitian ini telah mendapat persetujuan dari Komite Etik Penelitian Kesehatan Sekolah Tinggi Ilmu Kesehatan Bakti Tunas Husada Tasikmalaya (No: 077/kepk-bth/IV/2021).

\section{Hasil Penelitian dan Pembahasan}

Dari total 104 subjek yang bersedia mengikuti penelitian 12 subjek diantaranya tidak memenuhi kriteria dua subjek spesimen hemolisis dan sepuluh subjek memiliki nilai MCV > $80 \mathrm{fL}$, seperti terlihat pada gambar 1. MCV merupakan hasil pembagian antara nilai hematokrit dengan jumlah sel eritrosit, dimana nilainya $<80$ fL dapat digunakan untuk mendiagnosis talasemia beta minor (Brancaleoni et al., 2016), dengan sensitivitas $81,3 \%$ dan spesifisitas $95,8 \%$ (Setiawan et al., 2020). Sehingga subjek yang digunakan dalam penelitian ini terindikasi talasemia beta minor atau pembawa gen talasemia, dimana rerata MCV pada penelitian ini adalah 65 fL Karakteristik sampel penelitian ditunjukkan pada Tabel 1.

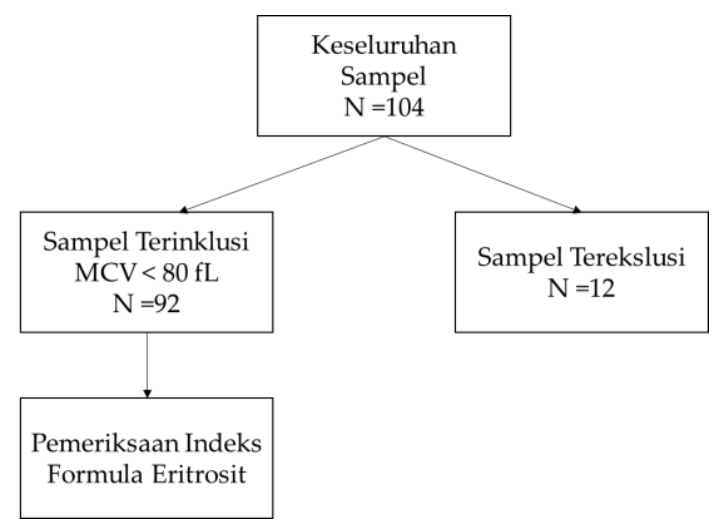

Gambar 1. Desain penelitian indek formula eritrosit

Tabel 1. Karakteristik sampel pemeriksaan indek formula eritrosit

\begin{tabular}{lll}
\hline Karakteristik & $\mathrm{n}$ & Median \\
\hline Usia (tahun) & & 41 \\
Jenis Kelamin & & \\
Laki-laki & 28 & \\
Perempuan & 64 & \\
Sampel Terinklusi & 92 & \\
Sampel eksklusi & 12 & \\
\hline
\end{tabular}

$\mathrm{n}:$ jumlah

Berdasar table 1 subjek responden banyak diikuti oleh perempuan dengan sebanyak 64 subjek, namun penyakit ini tidak terkait jenis kelamin. Hal ini karena talasemia bukan termasuk penyakit genetik yang disebabkan oleh faktor alel tekait dengan kromosom seks, tetapi disebabkan oleh faktor alel tunggal autosomal resesif (Rejeki et al., 2012). Rerata usia responden 41 tahun, hal ini membuktikan bahwa angka hidup talasemia beta minor lebih panjang dibandingkan dengan penderita talasemia mayor tanpa transfusi teratur umumnya meninggal lebih awal dari usia 20-30 tahun (Mohtasham-Amiri et al., 2018). Hal ini karena penderita talasemia 
minor tidak memiliki gejala atau hanya mengalami anemia ringan, sehingga tidak memerlukan terapi transfusi darah (Origa, 2017). Hasil pemeriksaan formula indek eritrosit ditunjukkan pada tabel 2.

Tabel 2 Hasil indeks formula eritrosit pada talasemia beta minor

\begin{tabular}{|c|c|c|c|c|}
\hline No. & Indeks formula eritrosit & Rumus* & Cut-off * & $\begin{array}{l}\text { Hasil Penelitian } \\
\text { (Mean) }\end{array}$ \\
\hline 1 & England and Fraser $(\mathrm{E} \& \mathrm{~F})$ & $\mathrm{MCV}-\mathrm{RBC}-(5 \mathrm{Hb})-3,4$ & $<0$ & $-0,68$ \\
\hline 2 & RBC & $\mathrm{RBC}$ & $>5$ & 5,6 \\
\hline 3 & Mentzer & $\mathrm{MCV} / \mathrm{RBC}$ & $<13$ & 12 \\
\hline 4 & Srivastava & $\mathrm{MCH} / \mathrm{RBC}$ & $<3,8$ & 3,7 \\
\hline 5 & Shine and Lal (S\&L) & $\mathrm{MCV} \times \mathrm{MCH} \times 0 / 01$ & $<1530$ & 1348 \\
\hline 6 & Bessman & RDW & $<14$ & 17 \\
\hline 7 & Ricerca & RDW/RBC & $<4,4$ & 3,0 \\
\hline 8 & Green and King $(G \& K)$ & $(\mathrm{MCV} 2 \times \mathrm{RDW}) /(100 \mathrm{Hb})$ & $<65$ & 64 \\
\hline 9 & Das Gupta & $\begin{array}{l}1,89 \text { RBC }-0.33 \text { RDW - } \\
3,28\end{array}$ & $>0$ & 6,8 \\
\hline 10 & Jayabose (RDWI) & $(\mathrm{MCV} \times \mathrm{RDW}) / \mathrm{RBC}$ & $<220$ & 198 \\
\hline 11 & Telmissani-MCHD & $\mathrm{MCH} / \mathrm{MCV}$ & $<0,34$ & 0,31 \\
\hline 12 & Telmissani-MDH & $(\mathrm{MCH} \times \mathrm{RBC}) / \mathrm{MCV}$ & $>1,75$ & 1,75 \\
\hline 13 & Huber-Herklotz & $\begin{array}{l}(\mathrm{MCH} \times \mathrm{RDW} / 10 \mathrm{RBC})+ \\
\mathrm{RDW}\end{array}$ & $<20$ & 23 \\
\hline 14 & Kerman I & $(\mathrm{MCV} \times \mathrm{MCH}) / \mathrm{RBC}$ & $<300$ & 247 \\
\hline 15 & Kerman II & $\begin{array}{l}(\mathrm{MCV} \times \mathrm{MCH} \times 10) /(\mathrm{RBC} \times \\
\mathrm{MCHC})\end{array}$ & $<85$ & 79 \\
\hline 16 & Sirdah & $\mathrm{MCV}-\mathrm{RBC}-(3 \mathrm{Hb})$ & $<27$ & 26 \\
\hline 17 & Ehsani & $\mathrm{MCV}-(10 \mathrm{RBC})$ & $<15$ & 9 \\
\hline 18 & Keikhaei & $\begin{array}{l}(\mathrm{Hb} \times \mathrm{RDW} \times 100) /(\mathrm{RBC} 2 \times \\
\mathrm{MCHC})\end{array}$ & $<21$ & 7 \\
\hline 19 & Nishad & $\begin{array}{l}0,615 \mathrm{MCV}+0,518 \mathrm{MCH}+ \\
0,446 \mathrm{RDW}\end{array}$ & $<59$ & 29 \\
\hline 20 & Wongprachum & $\begin{array}{l}(\mathrm{MCV} \times \mathrm{RDW} / \mathrm{RBC})-10 \\
\mathrm{Hb}\end{array}$ & $<104$ & 84 \\
\hline 21 & Sehgal & $\mathrm{MCV} 2 / \mathrm{RBC}$ & $<972$ & 789 \\
\hline 22 & Pornprasert & $\mathrm{MCHC}$ & $<31$ & 30 \\
\hline 23 & Sirachainan & $1,5 \mathrm{HB}-0,05 \mathrm{MCV}$ & $>14$ & 14 \\
\hline 24 & Bordbar & $|80-\mathrm{MCV}| \times|27-\mathrm{MCH}|$ & $>44,76$ & 106 \\
\hline 25 & Matos and Carvalho (MC) & $1,91 \mathrm{RBC}+0,44 \mathrm{MCHC}$ & $>23,85$ & 24 \\
\hline 26 & CRUISE & $\begin{array}{l}\mathrm{MCHC}+0,603 \mathrm{RBC}+ \\
0,523 \mathrm{RDW}\end{array}$ & $\geq 42,63$ & 43 \\
\hline
\end{tabular}

*Sumber : (Jahangiri et al., 2019)

Berdasarkan hasil pemeriksaan indeks formula eritrosit (tabel 2), nilai Mentzer, England and Fraser (E\&F), RBC, , Srivastava, Ricerca, Green and King (G\&K), Shine and Lal (S\&L), Das Gupta, Matos and Carvalho (MC), Jayabose (RDWI), Telmissani-MDH, Telmissani-MCHD, Kerman I, Kerman II, Sirdah, Huber-Herklotz, Ehsani, Keikhaei, Nishad, Bordbar, Sirachainan, Wongprachum, Sehgal, Pornprasert, dan CRUISE masih dalam range cut-off sesuai penelitian sebelumnya, hal ini menunjukan bahwa indeks formula eritrosit tersebut dapat digunakan sebagai skrining talasemia beta minor di Indonesia khususnya di Kabupaten Ciamis. Indeks formula tersebut memiliki sensitivitas, spesifisitas, negative predictive values (NPV), dan positive predictive values (PPV), pada table 3. Sensitivitas Shine and Lal (S\&L) memiliki sensitivitas paling tinggi yaitu $100 \%$ (table 3). Artinya indeks formula eritrosit tersebut memiliki kemampuan tes skrining untuk mendeteksi positif sejati, berdasarkan tingkat kepositifan sebenarnya, yang mencerminkan kemampuan tes untuk mengidentifikasi semua orang dengan benar (Trevethan, 2017). Tingkat sensitivitas yang tinggi dari alat uji diagnostik dibutuhkan untuk mendeteksi penyakit (Noerjanto et al., 2014). Pada penelitian lain di Indonesia indeks formulasi dengan cut-off kurang 1530 ini memiliki sensitivitas 98\% (Surjawan et al., 2017). Indeks formula eritrosit Shine \& Lal sangat membantu dalam skrining awal talassemia beta minor, karena indeks formula eritrosit ini dapat mengkonfirmasi mutasi pada IVS1nt5 (c.92 + 5 G > C), dan CD-26 (c.79G > A), yang merupakan mutasi umum di Bandung, Jawa Barat, Indonesia (Maskoen et al., 2019). 
Nilai cut-off indeks formula eritrosit Sirdah kurang 27 memiliki spesifitas 88,65\% (table 3), artinya indeks formula eritrosit menunjukkan kemampuan tes skrining untuk mendeteksi negatif yang sebenarnya, dan mengidentifikasi dengan benar orang yang tidak memiliki kondisi talasemia beta minor, dengan baik (Trevethan, 2017). Spesifisitas yang tinggi lebih dibutuhkan untuk memperkuat dugaan adanya suatu penyakit (Noerjanto et al., 2014). Penelitian lain menunjukkan sensitivitas indeks formulasi eritrosit ini pada populasi Indonesia nilai 58,7\% (Yohanes Salim, Ninik Sukartini, 2011).

Tabel 3 Sensitivitas, spesifisitas, NPV dan PPV indeks formula eritrosit

\begin{tabular}{|c|c|c|c|c|c|}
\hline No. & Indeks formula eritrosit & $\begin{array}{l}\text { Sensitivitas } \\
(\%)\end{array}$ & $\begin{array}{l}\text { Spesifisitas } \\
(\%)\end{array}$ & $\begin{array}{l}\text { NPV } \\
(\%)\end{array}$ & $\begin{array}{l}\mathrm{PPV} \\
(\%)\end{array}$ \\
\hline 1 & England and Fraser $(\mathrm{E} \& \mathrm{~F})$ & 62,94 & 85,4 & 86,22 & 61,36 \\
\hline 2 & $\mathrm{RBC}$ & 86,41 & 61,94 & 77,20 & 75,34 \\
\hline 3 & Mentzer & 89,01 & 78,65 & 85,82 & 83,14 \\
\hline 4 & Srivastava & 74,86 & 80,81 & 84,99 & 68,89 \\
\hline 5 & Shine and Lal (S\&L) & 100 & 17,57 & 63,78 & 100 \\
\hline 6 & Bessman (RDW) & 6,33 & 80 & 31,48 & 37,05 \\
\hline 7 & Ricerca & 98,70 & 7,03 & 60,64 & 78,79 \\
\hline 8 & Green and King $(\mathrm{G} \& \mathrm{~K})$ & 86,59 & 78,65 & 85,48 & 80,17 \\
\hline 9 & Das Gupta & 95,34 & 36,22 & 68,45 & 84,28 \\
\hline 10 & Jayabose (RDWI) & 92,55 & 64,32 & 79,01 & 85,61 \\
\hline 11 & Telmissani-MCHD & 98,32 & 3,51 & 59,66 & 59,09 \\
\hline 12 & Telmissani-MDH & 56,42 & 85,95 & 85,11 & 57,53 \\
\hline 13 & Huber-Herklotz & 22,53 & 85,95 & 69,94 & 43,32 \\
\hline 14 & Kerman I & 94,41 & 61,89 & 78,24 & 88,42 \\
\hline 15 & Kerman II & 88,64 & 82,16 & 87,82 & 83,29 \\
\hline 16 & Sirdah & 80,26 & 88,65 & 91,12 & 75,58 \\
\hline 17 & Ehsani & 89,01 & 81,35 & 87,39 & 83,61 \\
\hline 18 & Keikhaei & 88,64 & 72,70 & 82,50 & 81,52 \\
\hline 19 & Nishad & 85,29 & 77,03 & 84,35 & 78,30 \\
\hline 20 & Wongprachum & 87,90 & 69,46 & 80,68 & 79,81 \\
\hline 21 & Sehgal & 96,09 & 64,59 & 79,75 & 91,92 \\
\hline 22 & Pornprasert & 20,48 & 35,95 & 31,70 & 23,75 \\
\hline & Sirachainan & 35,94 & 74,86 & 67,48 & 44,61 \\
\hline & Bordbar & 97,21 & 55,40 & 75,98 & 93,18 \\
\hline
\end{tabular}




\begin{tabular}{llcccc}
\hline 25 & Matos and Carvalho (MC) & 78,58 & 79,46 & 84,74 & 71,88 \\
\hline 26 & CRUISE & 76,91 & 72,42 & 80,19 & 68,37
\end{tabular}

Sumber : (Jahangiri et al., 2019)

Dari tabel 2 menunjukan bahwa cut-off indeks formula eritrosit Bessman (RDW) kurang dari 14, tidak dapat digunakan skrining talasemia beta minor di Kabupaten Ciamis, karena hasil menunjukkan nilai 17. Hal ini, sama dengan penelitian lain nilai RDW lebih dari 21,0 dapat mengidentifikasi talasemia beta minor dengan tingkat akurasi diagnostik yang tinggi, dengan sensitivitas $81,3 \%$ dan spesifisitas 55,3\% (Piriyakhuntorn et al., 2018). Ini dikarenakan nilai cut-off kurang dari 14 dari indeks formula eritrosit tersebut memiliki sensitivitas sangat rendah yaitu 6,33\% (table 3). Artinya kemampuan mendeteksi talasemia beta minor sangat rendah. Indeks formulasi eritrosit Bessman menunjukkan akurasi diagnostik talasemia beta minor yang rendah, dan menyimpulkan bahwa diagnostik talasemia beta minor tidak dapat dilakukan hanya berdasarkan RDW. Tes ini memiliki kegunaan yang terbatas dalam skrining talassemia beta minor (Matos et al., 2015). Cell distribution width (RDW) merupakan kuantifikasi variasi ukuran sel darah merah (anisositosis), dengan nilai normal $13 \pm 1,5 \%$ (Nishad et al., 2014).

Pada penelitian lain indeks formula eritrosit yang baik untuk uji skrining diagnosis talasemia, dapat digunakan pada populasi Indonesia yaitu indeks Mentzer dan RDWI, dengan sensitivitas dan indeks Mentzer 86,85\% dan RDWI 88.14\%(Ayu NP, 2015). Cut-off baru Indeks Mentzer, RDWI, Green-King, dan Sirdah masing-masing adalah 13,$44 ; 233,4 ; 75,06$ dan 32,52. Semua indeks dapat diterapkan untuk masyarakat Indonesia, di antaranya Green-King Index memiliki nilai diagnostik terbaik, yaitu sensitivitas 96,9\%, spesifisitas 67,5\%, PPV 78,5\%, NPNV 94,7\% (Yohanes Salim, Ninik Sukartini, 2011).

Variasi nilai cut-off indeks formulasi eritrosit ini dikarenakan, variasi mutasi pada talasemia. Saat ini, terdapat lebih dari 200 mutasi titik dan delesi pada gen beta-globin (http://globin.cse.psu.edu/hbvar/menu.html). Berbagai jenis talasemia menghasilkan fenotipe klinis dan hematologi yang bervariasi. Jumlah eritrosit (RBC) dan indeks formula eritrosit sangat penting dalam diagnosis talasemia beta minor (Brancaleoni et al., 2016).

Upaya pertama untuk menggunakan indeks formula eritrosit dilakukan pada awal 1970-an. Studi tersebut dilakukan pada sampel kecil. Satu-satunya penelitian skala besar yang dipublikasikan dilakukan oleh Shine dan Lal pada tahun 1977. Beberapa dekade, lebih banyak upaya telah dilakukan dengan menggunakan metode indeks formula eritrosit konvensional untuk menemukan rumus yang andal, Sampel yang digunakan untuk memvalidasi indeks formula eritrosit untuk dimasukkan dalam penggunaan secara rutin harus cukup besar untuk dianggap dapat diandalkan. Hasil negatif palsu yang minimal diperlukan untuk memastikan keandalan indeks formula eritrosit. Sehingga dapat dimasukkan sebagai bagian dari analisis rutin dan akan memberikan peringatan ketika dicurigai adanya talasemia beta minor (Roth et al., 2018).

Pemeriksaan darah rutin dapat menunjukkan status talasemia beta minor secara signifikan pada pasangan yang berisiko. Selanjutnya pasangan tersebut dapat dirujuk untuk melakukan konseling genetik. Metode yang handal dan murah untuk skrining massal dari populasi diperlukan untuk memungkinkan pemilihan sampel untuk analisis Hb menggunakan HPLC untuk memastikan diagnosis (Roth et al., 2018).

\section{Kesimpulan}

Kedua puluh lima indeks formula eritrosit memiliki nilai sesuai cut-off penelitian sebelumnya, sehingga dapat digunakan untuk skrining beta talasemia di Kabupaten Ciamis, kecuali indeks formula eritrosit Bessman (RDW), yang memiliki nilai lebih besar cut-off tersebut. Variasi tersebut disebakan oleh variasi mutasi pada gen beta-globin.

\section{Daftar Pustaka}

Ayu NP, R. (2015). Indeks RDW dan Mentzer sebagai Uji Skrining Diagnosis Thalassemia. Majority, 4(7), 712.

Bordbar, E., Taghipour, M., \& Zucconi, B. E. (2015). Reliability of Different RBC Indices and Formulas in Discriminating between $\beta$-. Mediterranean Journal of Hematology and Infectious Diseases, 7(1), 1-5. https://doi.org/http://dx.doi.org/10.4084/MJHID.2015.022

Brancaleoni, V., Pierro, E. D. I., Motta, I., \& Cappellini, M. D. (2016). Laboratory diagnosis of thalassemia. Int. Jnl. Lab.Hem, 38, 32-40. https://doi.org/10.1111/ijlh.12527

Hossain, M. S., Raheem, E., Sultana, T. A., Ferdous, S., Nahar, N., Islam, S., Arifuzzaman, M., Razzaque, M. A., Alam, R., Aziz, S., Khatun, H., Rahim, A., \& Morshed, M. (2017). Thalassemias in South Asia: 
clinical lessons learnt from Bangladesh. Orphanet Journal of Rare Diseases, 12(1), 1-9. https://doi.org/10.1186/s13023-017-0643-z

Husna, N., Arif, A. Al, Putri, C., Leonard, E., \& Handayani, N. S. N. (2017). Prevalence and Distribution of Thalassemia Trait Screening. Journal of Thee Medical Sciences (Berkala Ilmu Kedokteran), 49(03), 106113. https://doi.org/10.19106/jmedsci004903201702

Jahangiri, M., Rahim, F., \& Malehi, A. S. (2019). Diagnostic performance of hematological discrimination indices to discriminate between $\beta$ eta thalassemia trait and iron deficiency anemia and using cluster analysis: Introducing two new indices tested in Iranian population. Scientific Reports, 9(1), 1-13. https://doi.org/10.1038/s41598-019-54575-3

Maskoen, A. M., Reniarti, L., Sahiratmadja, E., Sisca, J., \& Effendi, S. H. (2019). Shine \& Lal index as a predictor for early detection of $\beta$-thalassemia carriers in a limited resource area in Bandung, Indonesia. BMC Medical Genetics, 20(1), 1-6. https://doi.org/10.1186/s12881-019-0868-x

Matos, J. F., Borges, K. B. G., Fernandes, A. P. S. M., Faria, J. R., \& Carvalho, M. D. G. (2015). RDW as differential parameter between microcytic anemias in "pure" and concomitant forms. Jornal Brasileiro de Patologia e Medicina Laboratorial, 51(1), 22-27. https://doi.org/10.5935/1676-2444.20150005

Mohtasham-Amiri, Z., Khanaki, K., Davoudi-Kiakalayeh, A., Rezvani, S. M., Jafari-Shakib, A., \& JafariShakib, R. (2018). Analysis of survival in patients with $\beta$-thalassemia major in Guilan, Northern Iran. Iranian Journal of Blood and Cancer, 10(3), 82-86.

Nishad, A. A. N., De Silva, I. S., Perera, H. L., Pathmeswaran, A., Kastutiratne, K. T. A. A., \& Premawardhena, A. P. (2014). Role of red cell distribution width in screening for $\mathrm{Hb} \mathrm{E}$ trait in population screening for hemoglobin disorders. Journal of Pediatric Hematology/Oncology, 36(8), e490-e492. https://doi.org/10.1097/MPH.0000000000000052

Noerjanto, R. P. B., Savitri, Y., \& Putri, M. C. (2014). Sensitivitas, spesifisitas, dan akurasi pengukuran mental indeks pada radiografi panoramik wanita pascamenopause. Dentomaxillofacial Radiology Dental Journal, 5(1), 8-13. http://www.journal.unair.ac.id/filerPDF/radfkg8c0109472efull.pdf

Origa, R. (2017). $\beta$-Thalassemia. Genetics in Medicine, 19(6), 609-619. https://doi.org/10.1038/gim.2016.173

Piriyakhuntorn, P., Tantiworawit, A., Rattanathammethee, T., Chai-Adisaksopha, C., Rattarittamrong, E., \& Norasetthada, L. (2018). The role of red cell distribution width in the differential diagnosis of iron deficiency anemia and non-transfusiondependent thalassemia patients. Hematology Reports, 10(3), 7276. https://doi.org/10.4081/hr.2018.7605

Rejeki, D. S. S., Nurhayati, N., Supriyanto, S., \& Kartikasari, E. (2012). Studi Epidemiologi Deskriptif Talasemia. Kesmas: National Public Health Journal, 7(3), 139-144. https://doi.org/10.21109/kesmas.v7i3.61

Roth, I. L., Lachover, B., Koren, G., Levin, C., Zalman, L., \& Koren, A. (2018). Detection of $\beta$-thalassemia carriers by red cell parameters obtained from automatic counters using mathematical formulas. Mediterranean Journal of Hematology and Infectious Diseases, 10(1), 1-10. https://doi.org/10.4084/MJHID.2018.008

Setiawan, D., Farihatun, A., \& Nurmalasari, A. (2020). Skrining Talasemia Beta Minor pada Pelajar SMK di Kecamatan Ciamis. Jurnal Kesehatan Vokasional, 5(3), 180-188. https://doi.org/10.22146/jkesvo.57621

Surjawan, Y., Tan, H. L., Setiabudy, R. D., \& Rositawati, W. (2017). Early screening of hemoglobinopathy in Indonesia using erythrocyte indices. Indonesian Biomedical Journal, 9(2), 99-105. https://doi.org/10.18585/inabj.v9i2.313

Trevethan, R. (2017). Sensitivity, Specificity, and Predictive Values: Foundations, Pliabilities, and Pitfalls in Research and Practice. Frontiers in Public Health, 5(November), 1-7. https://doi.org/10.3389/fpubh.2017.00307

Yohanes Salim, Ninik Sukartini, A. S. (2011). Erythrocyte Indices To Differentiate Iron Deficiency Anemia From B Trait Thalassemia. Jurnal Indonesia, 21(3), 261-265. 